\title{
Wastes from pulp and paper mills - a review of generation and recycling alternatives
}

\section{(Resíduos da produção de papel e celulose - uma revisão da geração e alternativas de reciclagem)}

\author{
L.Simão ${ }^{1 *}$, D. Hotza ${ }^{2}$, F. Raupp-Pereira ${ }^{1,3}$, J.A. Labrincha ${ }^{4}$, O. R. K. Montedo ${ }^{1}$ \\ ${ }^{1}$ Universidade do Extremo Sul Catarinense, Programa de Pós-Graduação em Ciência e Engenharia de \\ Materiais, Grupo de Pesquisa VALORA, Av. Universitária 1105, P.O. box 3167, 88806-000, Criciúma, SC, Brazil \\ ${ }^{2}$ Universidade Federal de Santa Catarina, Departamento de Engenharia Química, Florianópolis, SC, Brazil \\ ${ }^{3}$ Universidade Federal de Santa Catarina, Departamento de Engenharia Mecânica, Florianópolis, SC, Brazil \\ ${ }^{4}$ Universidade de Aveiro, Departamento de Engenharia Cerâmica e de Materiais, Aveiro, Portugal
}

\begin{abstract}
The production of pulp and paper is increasing worldwide, and wastes are therefore being generated in appreciable amounts. Various materials are generated in pulp and paper mills, such as ash, dregs, grits, lime mud and pulp mill sludge. Over the years, these wastes have typically been sent to landfills or incinerated. However, with increased environmental awareness new alternatives have been investigated, especially the valorization of these materials. In this review, the characteristics of the manufacturing process, generated wastes, main destinations and recycling alternatives are addressed. The state of the art indicates that dregs are useful in agriculture as soil amendments, while lime mud can be used in agriculture and in environmental technology, mainly in wastewater treatment. Grits are commonly employed in construction, and pulp mill sludge shows applications in agriculture, construction and energy processes. In conclusion, this review shows several successful cases of recycling wastes from pulp and paper mills.
\end{abstract}

Keywords: paper, pulp, waste management.

Resumo

A produção de papel e celulose está aumentando em todo o mundo e consequentemente a geração de resíduos. Vários materiais são gerados neste processo, tais como cinzas, dregs, grits, lama de cal e lama de ETE. Ao longo dos anos, esses resíduos foram normalmente enviados para aterros ou incinerados. No entanto, com maior consciência ambiental, novas alternativas foram investigadas, especialmente na valorização desses materiais. Nesta revisão, as características do processo, os resíduos gerados e as principais alternativas de reciclagem são abordados. O estado da arte indica que os dregs e lama de cal podem ser usados na agricultura (corretivos de solo) e em tecnologias ambientais, principalmente no tratamento de águas residuais. Os grits são comumente empregados na construção e as lamas de ETE são aplicadas na agricultura, construção e processos energéticos. Em conclusão, esta revisão mostra vários casos bem-sucedidos na reciclagem de resíduos da produção de papel e celulose.

Palavras-chave: papel, celulose, gestão ambiental.

\section{INTRODUCTION}

The concept of sustainability has been applied over the years in all manufacturing activities, including pulp and paper mills, which represent an important worldwide economic activity and cause remarkable environmental impact [1]. In this context, waste management plays an important role in a modern management system [2] and becomes one of the requirements for attenuation of the generated impact, not only from the environmental stance but also from the economic and social points of view. According to the European Commission (EC) and the United States Environmental

*lisandrosimao@gmail.com
Protection Agency (USEPA), residues are classified as wastes and by-products [3, 4]. The Resource Conservation and Recovery Act (RCRA) §1004(27) of the USEPA defines solid waste as any garbage, sludge from a wastewater or water treatment plant, or any other discarded material (solid, liquid, semisolid, or contained gaseous material) resulting from industrial activities, commercial, mining, or agricultural operations or from communities. Likewise, a by-product is defined by RCRA §261.1(c) (3) [4] as a material that is not one of the primary products of a production process and is not solely or separately produced by the production process. A by-product may include most wastes that are not spent materials or sludge. The Directive of EC 2008/98/CE defines a by-product as any residue whose subsequent use without 
any further processing other than ordinary industrial practice is assured. The Directive of EC cites the appropriate legal actions to ensure that the waste category can be changed and be considered a by-product by environmental protection agencies. In this sense, studies on waste recycling to transform waste into by-products and generate minimal amounts of tailing are extremely important for sustainability.

Pulp and paper mill production is growing every year worldwide. As a consequence, the amount of generated waste is increasing, along with increasing concern and the importance of this topic. In 2013, world paper production reached $403 \mathrm{Mt}$, while pulp production reached $179 \mathrm{Mt}$ [5], with the USA, China, Canada, Brazil, Sweden, Finland, Japan, Russia, Indonesia and Chile being the top ten pulp producers [6]. Kinnarinen et al. [7] estimate that waste production is most likely over one million metric tonnes per year. Currently, various inorganic and organic substances are generated in pulp and paper mills, such as ashes, green liquor dregs, slaker grits, lime mud and pulp mill sludge of waste water treatment plants (WWTP) [8, 9]. When improperly disposed of, these wastes can have a significant impact on the environment, damaging the water, soil and air. The high organic matter content in wastewater treatment sludge can increase BOD levels in water and, in the worstcase scenario, cause the eutrophication of lakes, ponds and other hydric bodies. In soils, some undesirable elements, e.g. heavy metals, can harm the nutrient dynamics. Regarding air, the control of emissions in incinerators is essential to preserving the quality of life for the people. Thus, the waste must be intensely researched to mitigate the negative impacts and enhance the benefits of their use.

In many countries, the use of such waste has gained notoriety and importance. In the USA and China, for example, lime mud has been used in environmental technology $[10,11]$. Finland generates energy from wood waste and biological sludge [12]. In Brazil, green liquor dregs and lime mud have been used in agriculture as soil amendments [13, 14]. Other wastes have been used in construction [15]. The focus of these studies is developing environmentally friendly processes and products. Based on this goal, a review of the generation of pulp mill wastes and recycling alternatives plays a major scientific and technologic role, taking into account cleaner production and therefore sustainability. Biomass ashes are not included in this review because they are also generated by other production processes. Therefore, many studies are specifically related to this waste in the literature [16-23]. Thus, this work reviews the efforts of the pulp and paper production process to improve the productive performance and to reduce the use of natural resources.

\section{MANUFACTURING PROCESS AND WASTE GENERATION}

Kraft process; the primary source of fibers for paper production is wood (coniferous and deciduous) [24]. In addition to cellulose fibers, wood is composed of carbohydrates and lignin [12] that can be separated by mechanical or chemical processes [25]. The most widely used chemical route is the Kraft process (Fig. 1), which employs active chemical agents, such as sodium hydroxide $(\mathrm{NaOH})$ and sodium sulfide $\left(\mathrm{Na}_{2} \mathrm{~S}\right)$ [26]. The process is divided into six main stages: pulping, washing, evaporation, combustion, clarification and causticizing [27]. The first step of the Kraft process is pulping, where lignin is removed in a cooking chemical solution called white liquor [24]. The pulp from the digester (black liquor) undergoes a washing process (second step) to separate the fibers (pulp) from the chemical inputs and waste. The pulp fibers pass through several steps (dilution, refining and chemical addition) for the production of paper $[26,28]$, while the remaining black liquor is subjected to the recovery process of the inputs. In the recovery of the white liquor, the solution undergoes evaporation and combustion to increase the solids content. In combustion, the black liquor is burned to produce a mix of dissolved salts (mainly sulfides, carbonates, sulfates and sodium and potassium chlorides) known as smelt, whose wash generates green liquor [29]. The green liquor passes through two steps: i) clarification, where dregs are produced [30], and ii) causticizing (Eq. A) to regenerate the white liquor with the production of lime mud [28, 29]. The lime mud is usually calcined for the regeneration of $\mathrm{CaO}$ [31], representing $90 \%$ of the needed lime for the causticizing step [32]. The use of the recovered lime, coming from a lime kiln, is dissolved in water in a series of reactors, and the insoluble material removed is called grits [9, 12, 29]. Frequently, these industries run power generation units by burning surplus biomass and organic-rich wastes generated in the process (e.g., sludge from the wastewater treatment process, or WWTP), and ash and sand are the wastes associated with this activity [2].

$\mathrm{Ca}(\mathrm{OH})_{2(\mathrm{l})}+\mathrm{Na}_{2} \mathrm{CO}_{3(1)} \rightarrow \mathrm{CaCO}_{3(\mathrm{~s})}+2 \mathrm{NaOH}_{(1)}$

Characteristics of the wastes: pulp and paper mills produce large amounts of waste with compositions that vary in a wide range of values $[2,33]$. Some wastes are rich in nutrients that can be returned to the environment, reducing the amount disposed of in landfills [34]. In general, these wastes are considered non-hazardous wastes [24, 32, 35] and show high alkalinity, typically with $\mathrm{pH}>10$ (Table I). The grits are sandy in appearance and gray in color [28] and consist of sand, gravel, limestone $\left(\mathrm{CaCO}_{3}\right)$, impurities that concentrate the unreacted components in the process, and residual amounts of $\mathrm{CaO}, \mathrm{Ca}(\mathrm{OH})_{2}$ and $\mathrm{Na}_{2} \mathrm{CO}_{3}$ [36]. Grits may also contain portlandite $\left[\mathrm{Ca}(\mathrm{OH})_{2}\right]$, pirssonite $\left[\mathrm{Na}_{2} \mathrm{Ca}\left(\mathrm{CO}_{3}\right)_{2} \cdot 2 \mathrm{H}_{2} \mathrm{O}\right]$, larnite $\left(\mathrm{Ca}_{2} \mathrm{SiO}_{4}\right)$ and brucite $\left[\mathrm{Mg}\left(\mathrm{OH}_{2}\right)\right]$ [29]. Grits, green liquor dregs and lime mud represent the largest fraction of solids among all of the waste generated at pulp mills. The composition of grits varies widely, containing crystalline phases such as calcite [29] and several metal ions such as barium, chromium, copper, lead, nickel and zinc [8]. Chemical and mineralogical compositions reported in other studies [15, 29, 37] confirm that $\mathrm{CaCO}_{3}$ is the major component of lime mud; $\mathrm{CaO}$ 


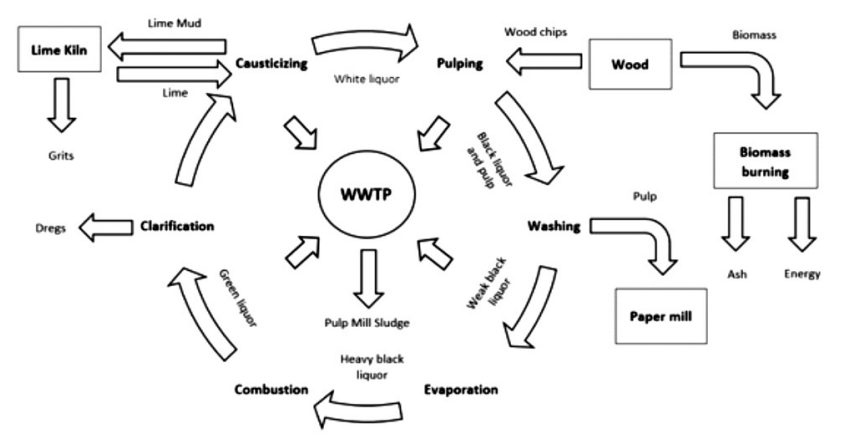

Figure 1: Kraft process and generated waste: green liquor dregs, lime mud, slaker grits, ash and pulp mill sludge of wastewater treatment plant - WWTP.

[Figura 1: Processo Kraft e geração dos resíduos: dregs, lama de cal, grits, cinzas e lama de ETE.]

and $\mathrm{Ca}(\mathrm{OH})_{2}$ are compounds also commonly detected, together with $\mathrm{Mg}, \mathrm{K}, \mathrm{Na}, \mathrm{Cr}, \mathrm{Mn}$ and $\mathrm{Fe}$ trace elements. According to [38], dregs show high amounts of $\mathrm{Na}, \mathrm{K}, \mathrm{Mn}$, $\mathrm{Mg}$ and $\mathrm{Zn}$, and the main crystalline phase is pirssonite $\left[\mathrm{Na}_{2} \mathrm{Ca}\left(\mathrm{CO}_{3}\right)_{2} 2 \mathrm{H}_{2} \mathrm{O}\right]$. This Ca predominance in dregs, lime mud and grits, registered in the literature, is shown in Table I. Other physical and chemical characteristics (moisture content and $\mathrm{pH}$ ) of these wastes are also shown.

The first step in WWTP is primary clarification, which generates the primary sludge. Primary clarification is usually carried out by sedimentation and sometimes by dissolved air (flotation) [39]. The generated wastewater is sent to the secondary (biological) treatment, where microorganisms convert soluble organic matter into carbon dioxide and water, consuming oxygen and reducing the level of biochemical oxygen demand (BOD) [12, 39]. These two treatments produce sludge with different characteristics. The sludge from WWTPs is predominantly composed of water $>50$ wt $\%$ ) and shows a pH ranging from 6.6 to 8.2 (Table II). Therefore, this sludge must be totally or partially dehydrated prior to any management action being implemented [25]. The sludge composition generally comprises organic matter, nitrogen and phosphorus, which can be used as macronutrient fertilizers in agriculture [32]. Table II shows the predominance of organic matter in pulp mill sludge (primary and secondary) according to the literature. The primary sludge is composed of low biodegradable organic matter (mainly cellulose fibers) [40] and by fillers (kaolinitic clay, calcium carbonate and titanium dioxide) but might show low amounts of $\mathrm{K}, \mathrm{Mg}, \mathrm{Na}$ and several toxic metals [ 25 , 41]. This sludge possesses high $\mathrm{C} / \mathrm{N}$ ratios (150 to 250) [40]. In some cases, ash and inert materials, which were rejected during the recovery process of the chemical products, are also found in the primary sludge $[2,39]$. The biological sludge is produced from treatment with microorganisms and is typically composed of activated sludge, cake from the filter press and sludge from the secondary decanters and thickeners [2]. This sludge presents a higher nutrient content compared to primary sludge [25], resulting in a low $\mathrm{C} / \mathrm{N}$ ratio (5 to 30$)$ [40]. In many cases, both sludges are mixed
Table I - Physical and chemical characteristics of dregs, lime mud and grits.

[Tabela I - Características físicas e químicas dos dregs, lama de cal e grits.]

\begin{tabular}{ccccc}
\hline Waste & Moisture (\%) & $\mathrm{pH}$ & $\mathrm{Ca}(\mathrm{wt} \%)$ & Ref. \\
\hline & - & 10.7 & 35.4 & {$[13]$} \\
& 50.0 & 12.0 & 23.0 & {$[49]$} \\
Dregs & - & 12.2 & 25.0 & {$[30]$} \\
& 48.0 & 11.0 & 29.8 & {$[53]$} \\
& - & - & 32.4 & {$[29]$} \\
& 57.0 & 10.4 & 26.9 & {$[54]$} \\
\hline \multirow{4}{*}{ mime } & - & 13.0 & - & {$[58]$} \\
& 32.4 & 12.6 & 38.5 & {$[53]$} \\
& - & - & 36.0 & {$[29]$} \\
& - & 12.0 & 59.0 & {$[37]$} \\
& 1.1 & 12.1 & - & {$[67]$} \\
& - & - & 37.4 & {$[65]$} \\
& - & 11.5 & 35.4 & {$[15]$} \\
\hline \multirow{4}{*}{ Grits } & - & 12.6 & 41.7 & {$[30]$} \\
& 16.0 & - & 36.8 & {$[26]$} \\
& - & - & 53.0 & {$[36]$} \\
& - & - & 34.6 & {$[29]$} \\
& 7.0 & 12.8 & 42.0 & {$[27]$} \\
& - & - & 68.7 & {$[35]$} \\
\hline
\end{tabular}

Table II - Physical and chemical characteristics of pulp mill sludge.

[Tabela II - Características físicas e químicas da lama de ETE.]

\begin{tabular}{ccccc}
\hline $\begin{array}{c}\text { Pulp mill } \\
\text { sludge }\end{array}$ & $\begin{array}{c}\text { Moisture } \\
(\%)\end{array}$ & $\mathrm{pH}$ & $\begin{array}{c}\text { Organic } \\
\text { matter }(\mathrm{wt} \%)\end{array}$ & Ref. \\
\hline \multirow{4}{*}{ Primary } & - & 6.6 & - & {$[79]$} \\
& - & 6.6 & $36.0-47.0$ & {$[25]$} \\
& 77.1 & 6.7 & 47.8 & {$[73]$} \\
\hline \multirow{3}{*}{ Secondary } & 67.0 & 8.0 & - & {$[2]$} \\
\hline & - & 7.7 & - & {$[79]$} \\
& - & 7.2 & $35.0-45.0$ & {$[25]$} \\
& 52.7 & 6.8 & 58.8 & {$[72]$} \\
\hline
\end{tabular}

to facilitate handling and may be dried to decrease their volume [12, 39]. Fig. 2 shows the appearance of the typical wastes produced from a Kraft process from a Brazilian pulp and paper mill, i.e. green liquor dregs, lime mud, slaker grits and pulp mill sludge. 


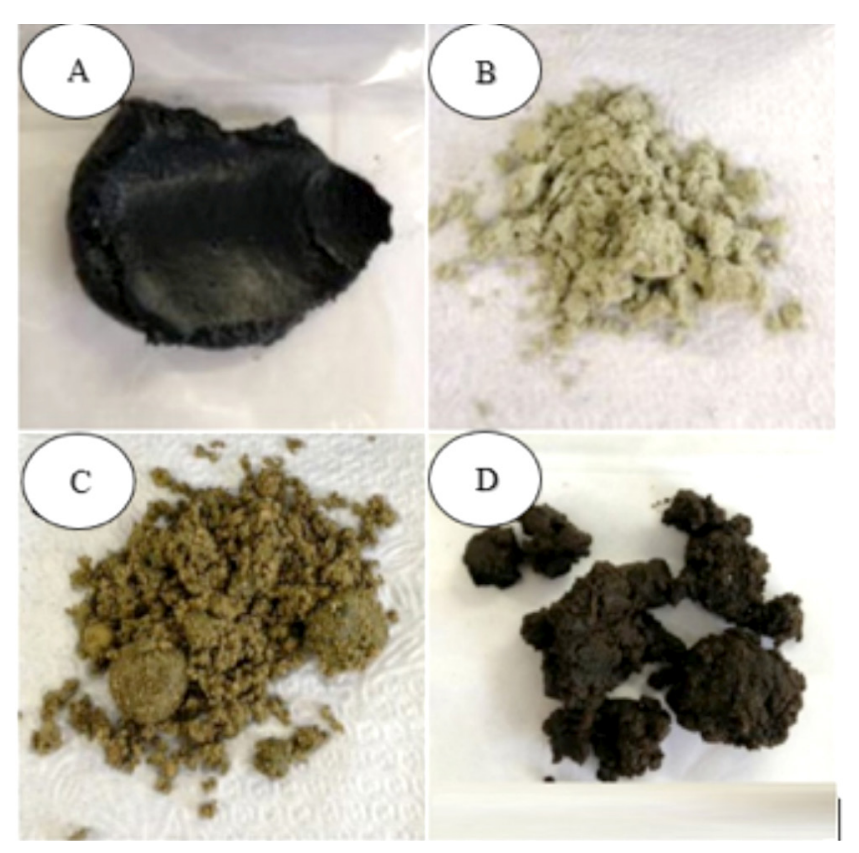

Figure 2: Wastes of Kraft process: A - dregs, B - lime mud, C - grits, and D - pulp mill sludge.

[Figura 2: Resíduos do processo Kraft: A - dregs, B - lama de cal, C - grits e D - lama de ETE.]

\section{FINAL DESTINATION AND RECYCLING}

When analyzing the waste disposal alternatives in a particular industry, the generated quantity should be considered, and changes in the production that minimize waste generation are decidedly welcome [42]. For instance, the continuous improvement of waste management in a plant in Finland reduced waste generation from 43 to $6 \mathrm{Mt}$ (wet weight) between 1994 and 2004 [12]. Taking into account more rigid environmental legislation and increasing disposal costs, adopting new treatment technologies or implementing process changes are gaining importance minimizing waste generation. One of the challenges in the management of pulp and paper mill waste is the low solids content of several streams. According to [43], $60 \%$ of the costs involved in wastewater treatment are related to the disposal of the produced sludge. Fig. 3 shows the main changes in the WWTP and post-treatment steps conducted to reduce the amount of sludge.

Extended aeration and generation of smaller bubbles are possible changes to be implemented in wastewater treatment

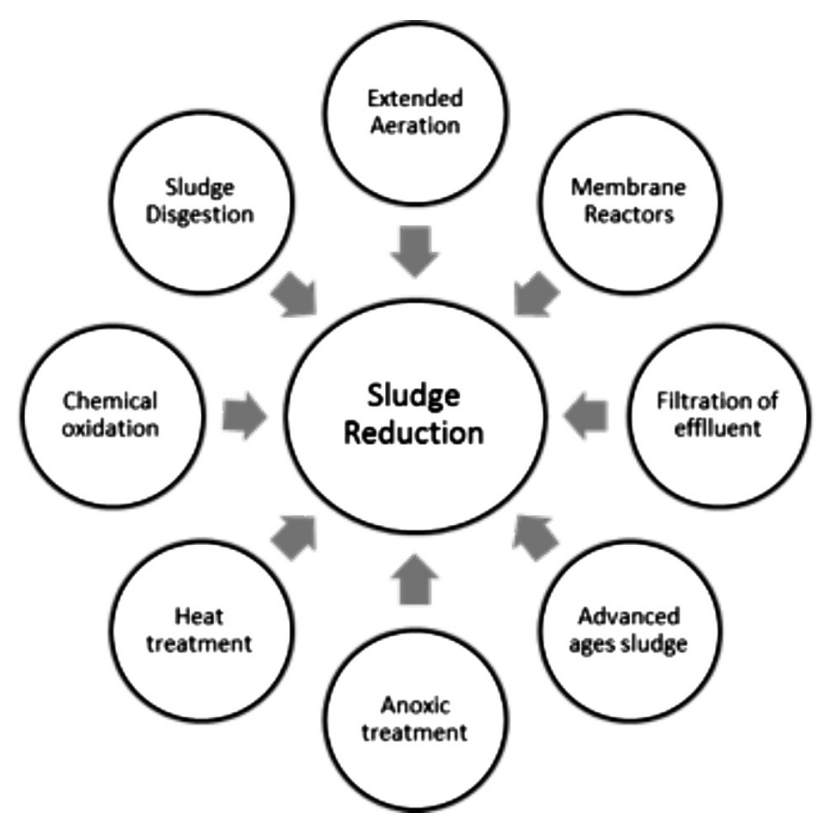

Figure 3: Outline of sludge reduction technologies.

[Figura 3: Esboço das tecnologias de redução de lama de ETE.]

because organic matter degradation may be improved, and therefore less sludge may be generated. The use of membrane bioreactors, effluent filtration and sludge with advanced ages improve effluent quality and also decrease the volume of the generated waste. Introducing an anoxic treatment step to promote denitrification has also been reported in the literature, and the sludge volume can be reduced by means of heat or chemical treatments. Moreover, drying, pelletizing/ granulation and heat treatment processes can be used to adapt the waste for further valorization while minimizing its volume [34,44]. Worldwide, landfilling is the most common destination for such wastes, but the high (and increasing) volumes involved and the possible presence of hazardous elements in some streams impose environmental constraints to this practice. As already mentioned, legislation is also becoming more restrictive and costs are increasing [45]. Any potential recycling alternative requires the full determination of relevant characteristics of the waste. For landfilling, the composition and leaching behavior must also be known [12]. As will be detailed later, agriculture, construction, energy generation, and environmental technology are the most explored fields for recycling such wastes [46, 47]. Table III lists some work conducted in these fields.

Table III - Works on reuse of pulp and paper mill wastes.

[Tabela III - Trabalhos de reuso dos resíduos do processo de obtenção de papel e celulose.]

\begin{tabular}{ccccc}
\hline Waste & Agriculture & Construction & Energy & Environmental technology \\
\hline Dregs & {$[13,14,27,30,34,49-52]$} & - & - & {$[12,27,53,54]$} \\
Lime mud & {$[15,27,34,58,59]$} & {$[61,62]$} & - & {$[9,37,67]$} \\
Grits & - & {$[28,35,36,69]$} & - & - \\
Pulp mill & {$[25,32,72-75,77-82,102]$} & {$[83,45,24,84,85,86$,} & {$[42,90,94$} & - \\
sludge & & $2,41,87,63,44]$ & $98,99]$ & - \\
\hline
\end{tabular}




\section{Green liquor dregs}

Green liquor dregs have been mostly applied in agriculture and environmental technology fields (Table III).

Agriculture: the use of alkaline waste in agriculture to correct soil acidity and fertilizer has been widely investigated. Medeiros et al. [14] evaluated the physical and chemical changes caused by the addition of dregs in aluminic soil (Humic Cambisol) for a wheat crop. The results were compared to those obtained with a conventional corrective (limestone). The increased waste content of the mix increased the $\mathrm{pH}$ values to 6 and improved the soil chemistry properties. Pértile et al. [48] evaluated the development of a type of pine (Pinus taeda L.) and the variation of the physical and chemical properties of an acidic soil. The results showed an improvement in the soil fertility and reduced acidity. The increased base saturation was found to be similar to that reached with limestone, and no adverse effects were found on the average diameter of the plants. In addition to the liming effect, Almeida et al. [13] reported that dregs can be a source of calcium and micronutrients for the plants. Productivity rates were found to be similar to those obtained using commercial limestone. However, some negative aspects must be taken into consideration in relation to this practice, as cited in [49]. The authors determined the influence of dregs in the soil chemical properties and the leaching of phenolic compounds. The analysis of the leachate showed that the application of the dregs increased the content of these compounds to values above the limit allowed by law. In other works, similar positive results were found using dregs in the soil. Zambrano et al. [50] showed that the physical and chemical characteristics of the waste are useful for plants, and the research confirmed their potential use on degraded soils in Chile. In Sweden, Österås et al. [51] concluded that in a long-term perspective the use of such wastes does not increase the accumulation of heavy metals in plants. Lu et al. [52] showed that the phytotoxicity is not a problem for land application in Taiwan. These authors also reported the use of dregs combined with WWTP sludge in composting. High $\mathrm{CO}_{2}$ production rates and accentuated losses of the total volatile compounds were obtained after 3 days of composting, and a stable compound was produced after 7 days.

Environmental technology: in this field, most studies tried using dregs in wastewater treatment or as a landfill cover component. In wastewater treatment, dregs have been applied for neutralizing acidic waters in Finland [12]. Pöykiö [27] and Manskinen et al. [38] showed the effects of liming with 34.2 and $39.6 \mathrm{wt} \% \mathrm{Ca}$, respectively, similar to commercial lime (38 wt\% Ca). The heavy metal contents measured in the tested dregs were well below the limits for fertilizers used in forestry [38]. The dregs were mostly composed of carbonates and were strongly alkaline ( $\mathrm{pH} 11.7)$. Pöykiö [27] also related increased heavy metal content in the sludge generated from wastewater treatment, confirming the high retention of such species by the dregs. The use of dregs as an alternative material to create landfill covering layers is possible due to their high buffering capacity. By assuring high $\mathrm{pH}$ values for longer periods, they improve the immobilization of chemical elements at very low contents (up to ppb) in the waste [53]. Mäkitalo [54] studied the use of dregs as a sealing material for preventing acid mine drainage in Sweden because the waste has a low hydraulic conductivity and high alkalinity. The water retention capacity proved to be as good as that assured by clay-based layers, normally used for this purpose, allowing the sealing to be saturated even in times of drought. This result means greater difficulty for oxygen penetration and therefore lower oxidation of tailings. The alkalinity of the dregs showed a direct effect on the stability of certain elements, extending the benefits of using this potential waste. Mäkitalo et al. [55] also evaluated the long-term efficiency of green liquor dregs sealing layers along the years. Green liquor dregs fresh and aged (3 to 13 years) were collected and analyzed to determine how aging affects its chemical and physical properties. The results showed no significant effect of aging on the evaluated properties in a sealing layer.

\section{Lime mud}

The composition of lime mud can vary depending on the raw materials but mainly depends on the operational conditions. The lime mud might contain distinct (but normally low) amounts of toxic compounds, and some recycling routes are also limited by the presence of chlorides [56, 57]. Table III summarizes the recycling attempts already reported, which include agriculture, construction and environmental technology.

Agriculture: the use of lime mud as a corrective and soil fertilizer has been investigated in agriculture. He et al. [58] investigated the liming effect of the mud (four distinct charges: $2.25,4.51,9.01,22.50 \mathrm{t} / \mathrm{ha}$ ) in soils used to grow Lolium perenne L. ryegrass in the USA. The $\mathrm{pH}$ of the soil initially increased due to the application of lime mud but then declined over the 6-week testing period. Concentrations between 4.51 and 9.01 dry t/ha were found to be more beneficial for the growth of the grass. The effects of lime mud as a buffering agent and provider of inorganic nutrients for the anaerobic digestion of food waste were investigated in China [59]. Higher process stabilization and efficiency were obtained using sludge contents ranging from 6 to 10 $\mathrm{g} / \mathrm{L}$ because the release of alkaline substances favors the methanogenic process. High $\mathrm{CH}_{4}$ production $(273 \mathrm{~mL} / \mathrm{g} \mathrm{SV})$ was obtained using sludge and volatile solid contents of 10.0 to $19.8 \mathrm{~g} / \mathrm{L}$, respectively, with a final $\mathrm{pH}$ of 8.4 . Zhang et al. [60] used lime mud to increase the efficiency of sewage sludge digestion. Batch tests were performed at $55^{\circ} \mathrm{C}$ with different lime mud concentrations (1.25 to $5.00 \mathrm{~g} / \mathrm{L})$. The best result was achieved for $2.50 \mathrm{~g} / \mathrm{L}$ of lime mud, with $\mathrm{CH}_{4}$ production of $146 \mathrm{~mL} / \mathrm{g} \mathrm{SV}$ and $42.4 \%$ of volatile solid reduction.

Construction: in this sector, the use of lime mud has gained visibility in recent years. The compositional similarity between this waste and commercial $\mathrm{CaCO}_{3}$ was the primary 
motive for exploring the substitution of the primary resource with the waste in several building materials. Buruberri et al. [61] replaced $\mathrm{CaCO}_{3}$ with lime mud in the manufacture of clinker, while Modolo et al. [62] evaluated the properties (fresh and hardened condition) of mortars containing lime mud in Portugal. The use of lime mud as an aggregate tends to change the rheology of the mortar. In general, the fluidity decreases due to the improved cohesion between particles, but this effect is easily corrected. In the hardened state, the relevant properties of the mortars are not strongly affected by the waste addition. In Turkey, Sutcu and Akkurt [63] produced porous and lightweight bricks that showed lower thermal conductivity but suitable compression strength. Mixtures containing up to $30 \mathrm{wt} \%$ waste were prepared. The density of the bricks $\left(1.28 \mathrm{~g} / \mathrm{cm}^{3}\right)$ was reduced by up to $33 \%$; the total shrinkage was lower $(1-2 \%)$ than that of the reference bricks (3\%) and the thermal conductivity was $<0.4 \mathrm{~W} / \mathrm{m} . \mathrm{K}$, approximately half that of the reference bricks $(0.8 \mathrm{~W} / \mathrm{m} . \mathrm{K})$. These authors concluded that the waste is an interesting pore-forming additive. Qin et al. [64] used lime mud and fly ash as raw materials to produce anorthite ceramics in China. Samples using 36, 40, 50 and $60 \mathrm{wt} \%$ lime mud were analyzed. The formulations were pressed and sintered between 900 and $1250{ }^{\circ} \mathrm{C}$ for $2 \mathrm{~h}$. The results showed that the best lime concentration and temperature were $36 \mathrm{wt} \%$ and $1100{ }^{\circ} \mathrm{C}$, respectively, forming only anorthite phases in the samples. Increased lime mud content increased the water absorption values while decreasing the compressive strength. In conclusion, using lime mud and fly ash as raw materials to produce anorthite-based ceramics is a feasible approach to recycle such waste.

Environmental technology: in this field, studies have explored the high alkalinity of the waste [56] and its major component $\left(\mathrm{CaCO}_{3}\right)$ to precipitate heavy metals $[9,65]$, remove phosphorus [66], stabilize sewage sludge [10], and immobilize heavy metals $[10,11]$. The lime mud could be activated with sulfuric and hydrochloric acids, creating tunable microporous structures suitable for adsorption of organic matter from wastewater [57]. Sthiannopkao and Sreesai [67] reported the combined use of lime mud and biomass ash in wastewater treatment from metallurgy industries in Thailand. These streams are normally strongly acidic and contain relatively high solids load, including $\mathrm{Cr}, \mathrm{Cu}, \mathrm{Pb}$ and $\mathrm{Zn}$ components. The heavy metals are removed by precipitation and adsorption processes. Optimal removal rates of $93 \% \mathrm{Cr}, 99 \% \mathrm{Cu}, 96 \% \mathrm{~Pb}$ and $99 \% \mathrm{Zn}$ were obtained for a $45 \mathrm{~min}$ reaction time. The precipitation of heavy metals in wastewater with lime mud was also investigated by Wirojanagud et al. [9] using a jar-test. Labprepared solutions were made for each of the following heavy metals: lead $\left(1,434 \mathrm{mg} \mathrm{Pb}^{2+} / \mathrm{L}\right)$, chromium $(507 \mathrm{mg}$ $\left.\mathrm{Cr}^{3+} / \mathrm{L}\right)$, cadmium $\left(1,095 \mathrm{mg} \mathrm{Cd}^{2+} / \mathrm{L}\right)$, and mercury $(9.4 \mathrm{mg}$ $\left.\mathrm{Hg}^{2+} / \mathrm{L}\right)$. Additionally, a real wastewater sample containing $74.5 \mathrm{mg} \mathrm{Cr}^{3+} / \mathrm{L}$ and a COD of $683 \mathrm{mg} \mathrm{Hg}^{2+} / \mathrm{L}$ was tested. High removal efficiency was obtained for $\mathrm{Pb}, \mathrm{Cd}$ and $\mathrm{Hg}$ (90\%) and for $\mathrm{Cr}(100 \%)$. However, the $\mathrm{Hg}$-COD removal reached only $67 \%$.

\section{Slaker grits}

Grits are a solid waste rich in calcium carbonate that can be substituted for primary calcareous resources [35], mainly in building materials (Table III).

Construction: most works have focused on the use of grits in road paving [36], as an aggregate (sand replacement) in mortar formulations [68] and as a raw component of clinker [26]. Miranda et al. [28] produced soil-cement bricks containing different amounts of grits $(0,25,50,75$ and $100 \mathrm{wt} \%$ ), and the best results were obtained for the addition of $50 \mathrm{wt} \%$ grits. The waste-containing bricks developed compressive strength at 28 days of curing that was always above the limit defined by the standard ( $\geq 2$ $\mathrm{MPa}$ ). The strength tends to increase for higher grit levels in the formulations. Another work [69] on similar products confirmed these observations, and the optimal formulation, established according to the (maximum) compression strength and the (minimum) water absorption values, was the mix with $62.5 \mathrm{wt} \%$ grits. The replacement of Portland cement with grits in the production of soil-cement blocks was also studied in [35]. For up to $20 \mathrm{wt} \%$ replacement levels, the relevant properties of the product are not significantly affected, proving that grits might constitute a secondary source of calcite as filler in the mix.

\section{Pulp mill sludge}

Like some of the previous waste streams, the recycling routes explored for sludge (see Table III) include agriculture and building materials. The higher content of organic and combustible compounds present in the sludge supports their use for energy and power generation [70, 71]. Fig. 4 summarizes the processes discussed in this review.

Agriculture: some studies reported the use of sludge for composting. In some cases, a fertilizer was added to increase the nutrient content of the produced humus. Although the need for large areas to implement this solution represents the main disadvantage, the overall costs are relatively lower than for other routes [72-74]. Gea et al. [72] studied the composting of sludge samples at laboratory scale in Spain using samples from the de-inking process (PCS) and biological sludge (BS). Despite its poor characteristics (high $\mathrm{C} / \mathrm{N}$ ratio and low organic matter content and moisture), PCS showed excellent behavior in the composting. Thermophilic temperatures were achieved and maintained for more than seven days; thus, complete hygienization was obtained. Complete stabilization of the material was demonstrated by respiration tests, corroborating the other results. Hackett et al. [73] used mixes of primary and secondary sludge (70:30 wt\%) and fly ash for compost in Canada. Samples were mixed to yield a 50:50 (v/v) mixture of sludge and ash. The moisture content was maintained above $50 \mathrm{wt} \%$, and the final compost showed a $\mathrm{pH}$ of 8.5, high nutrient contents and a C:N ratio of 43:1. All of the metal contents, PCBs, PAHs and chlorophenol were below the levels required by local regulations. Over the first 8 weeks 


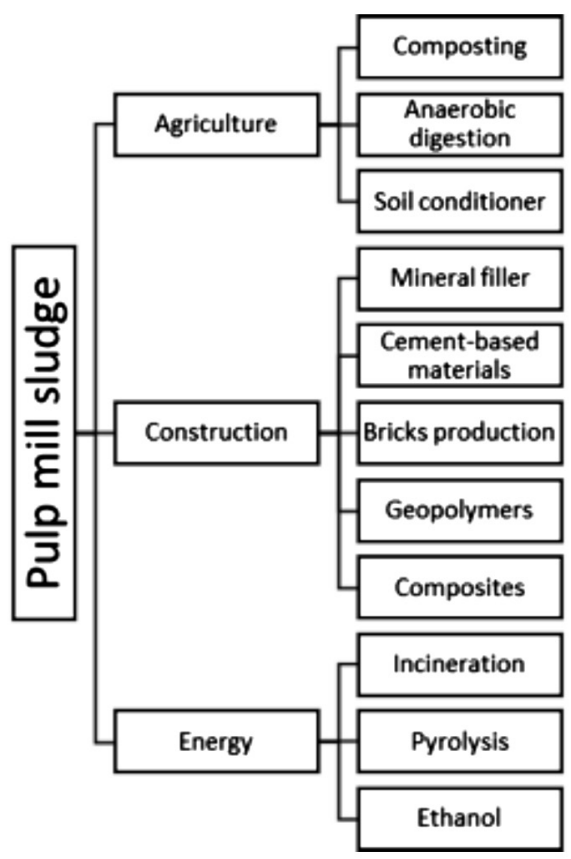

Figure 4: Fields of application of pulp mill sludge suggested in the literature.

[Figura 4: Campos de aplicação da lama de ETE sugeridas na literatura.]

of the composting period, the dioxin contents decreased by $45 \%$ and the application of the compost improved the soil characteristics. The authors concluded that the compost produced is acceptable as a low-cost soil conditioner to be used on sod farms and golf courses and for the recovery of land reclamation sites. Anaerobic digestion has been widely researched in recent years, mainly for secondary sludge, although the average generation of primary sludge is greater than the biological sludge [74-77]. Puhakka et al. [78] studied the anaerobic digestion of secondary sludge in pilot-scale trials in Finland. The results showed a median removal of volatile solids (VS, $40 \%$ ) for the median biogas production of $220 \mathrm{~L} / \mathrm{kg} \mathrm{VS}_{\text {added }}$ or $570 \mathrm{~L} / \mathrm{kg} \mathrm{VS}_{\text {removed }}$. Anaerobic digestion of primary sludge and co-digestion with secondary sludge were also studied in continuously stirred tank reactors (CSTR) and under thermophilic conditions. At the temperatures used in the work [79], the results showed a potential methane production of 210 and $230 \mathrm{~m}^{3} / \mathrm{VSS}_{\text {added }}$ for primary sludge at $35^{\circ} \mathrm{C}$, and 50 and $100 \mathrm{~m}^{3} / \mathrm{t} \mathrm{VS}_{\text {added }}$ for secondary sludge at $55^{\circ} \mathrm{C}$.

Primary sludge, secondary sludge and a mixture of the two may determine the soil basicity and then achieve an interesting liming effect. Southern European countries, such as Portugal and Spain, have a special interest in this evidence. Most of these countries' soils are acidic and have low organic matter content. Additionally, rainfall is generally low and irregular, and risks of erosion are strong. One of the main reported problems is the leaching of nitrates and the concomitant groundwater contamination. Other concerns are the presence of chlorine in the sludge and the potential formation of organochlorine compounds that may impair the soil. Conversely, in northwestern Europe, the soil and rainfall characteristics are opposite and the composting is not required (as much). Thus, incineration is the common practice for the disposal of sludge in this region [25]. Gallardo et al. [80] studied soils of volcanic origin in Chile (Andisol Gorbea Series and Argisol - Collipulli Series) and evaluated the effects of secondary sludge addition. Sludge loads of up to $50 \mathrm{t} / \mathrm{h}$ a were applied. The results showed that the microbial and enzyme activity significantly increased when the sludge rate was enhanced. This significant increase was statistically confirmed with a p-value of $(\mathrm{P})<0.05$. The maximum levels of biological activity were found to occur between 15 and 30 days after sludge application for loads between 30 and $50 \mathrm{t} / \mathrm{ha}$. Gallardo et al. [81] reported that secondary sludge improves the soil properties, increases the organic matter content and increases phosphorus. Thus, an improvement in the biological properties and the nutrient dynamics may be achieved, which proves the potential of using sludge as a soil conditioner. In Belgium, Nkana et al. [82] studied the effects of secondary sludge on the soil nutrient dynamics using columns of mixed samples from three tropical soils (Kandiudult). The soil columns were leached for 90 days with deionized water in amounts equivalent to the annual local precipitation. For all of the soils, the application of sludge increased the $\mathrm{Ca}, \mathrm{Mg}, \mathrm{SO}_{4}$, dissolved organic carbon (DOC) and inorganic carbon concentrations. Compared to liming, the application of wastes reduced $\mathrm{NO}_{3}$ leaching due to the high $\mathrm{C} / \mathrm{N}$ ratio of the sludge. With respect to nutrients, even after leaching, the most significant change was a substantial increase of $\mathrm{Ca}$ in the treated soil, associated with enhanced soil retention.

Construction: in the building sector, the use of sludge as filler is widely adopted. Ahmadi and Al-Khaja [83] used paper waste sludge as a sand replacement in concrete mixes. Five compositions containing up to $10 \mathrm{wt} \%$ wastes were prepared at the ratio of 1:3:6 by weight of cement, sand and aggregate, respectively. The results revealed that the elevation of the waste content increases the amount of water needed to prepare and knead the mixture because the sludge particles have increased water uptake. Sand for sludge substitution of up to $5 \mathrm{wt} \%$ can successfully be applied to the concrete mix. Values of the compressive strength (8 MPa) and water absorption (11.9\%) were compatible with the reference samples. Several other studies investigated the addition to cement-based materials, for example, to produce fiber-cement structures. This type of material is commonly used in covering roofs but can be applied in diverse construction products. Modolo et al. [2] replaced 25\% of the VLFP with primary sludge. The chemical characterization of the sludge did not show undesirable compounds, and the measured properties of the produced bodies are compatible with the product requirements. Yadollahi et al. [84] investigated WWTP sludge-containing cements. Compositions containing 40, 50 and $60 \mathrm{wt} \%$ sludge were prepared, and the results showed that the bending strength decreased with the relative amount of sludge. Values of approximately $22.7 \mathrm{kPa}$ were obtained for samples containing 
$40 \mathrm{wt} \%$ waste. The influence on the mechanical properties was related to the possible interference of this waste in the cement hydration process. The water absorption and consequent thickness swelling significantly increased with the sludge level in the mix. Other authors have evaluated the use of sludge in geopolymers. The properties of fresh and hardened geopolymeric mortars were successfully evaluated by Yan and Sagoe-Crentsil [85]. The average compressive strengths at 91 days of curing using 2.5 to $10 \mathrm{wt} \%$ of de-inking sludge were $92 \%$ and $52 \%$, respectively, of the reference value (60.6 $\mathrm{MPa}$ ). Shrinkage upon curing decreased by approximately 34 and $64 \%$, respectively, for the mentioned samples. The water absorption at room temperature also decreased when the sludge content increased. With some improvements in the properties, namely, decreasing the water absorption values due to the presence of residual organic matter and cellulose fibers in the samples, the authors concluded that sludge might be used for some applications in the building sector. Martínez et al. [86] used sludge from WWTP and waste from cleaning the pulp in ceramic materials. Increased linear thermal expansion and water absorption values of the fired samples were observed when the waste level increased, while the mechanical strength decreased but still satisfied the required standards. The pozzolanic activity of de-inking calcined sludge was determined in [44]. Samples were calcined at distinct times and temperatures and then mixed with Portland cement (CEM I 52.5N, $10 \mathrm{wt} \%$ sludge $/ 90 \mathrm{wt} \%$ cement). The sludge was mostly composed of calcite and kaolinite and revealed high pozzolanic reactivity. Optimal preparation conditions were reached at $700{ }^{\circ} \mathrm{C}$ for $2 \mathrm{~h}$. The produced blends complied with the physical-chemical specifications of the corresponding European standard (EN 197-1, 2011). The compressive strength at 7 days increased by approximately $10 \%$ when sludge was added to the cement compared to the values obtained with pure cement [24].

In brick production, the addition of 5-15 wt $\%$ sludge improves product properties as well as the manufacturing process. The porosity is enhanced by increasing the fiber content in the formulations, hence, lighter bricks are obtained. Sludge helps to save fuel in the kiln and decrease the firing time. Moreover, the cracking resistance during the drying and firing steps is improved [45]. Recently, studies have demonstrated the potential use of primary sludge (PS) as a reinforcing agent (fibers) and of secondary sludge (SS) as a binder in wood-plastic composites. The effect of different SS:PS ratios on the mechanical properties of this composite was studied. PS and SS were obtained from three different pulping processes: thermo-mechanical (TM), chemical-thermo-mechanical (CTMP) and Kraft processes. In this study, two SS:PS ratios (1:9 and 3:7) were used to obtain the mixtures. Three contents of those mixtures $(20,30$ and $40 \mathrm{wt} \%$ ) were added to a high-density polyethylene (HDPE) matrix. The results showed that the Kraft process sludge is the most suitable candidate for producing composites with better mechanical properties due to its higher pulp fiber content and longer fibers. Lower values of tensile strength, bending and impact were obtained with the mixture containing a 3:7 ratio compared to the 1:9 ratio. Water absorption and swelling increased with increased mixture content in the composites, and the bending strength and tensile strength improved [87]. Donmez Cavdar et al. [88] studied the obtainment of wood cement boards (WCB) using pulp mill sludge. A 1:3 wood:cement ratio was used for the replacement of wood by the sludge at up to $20 \mathrm{wt} \%$. The results were considered acceptable according to the limits stablished by European standard EN 634-2 for up to $10 \mathrm{wt} \%$ wood replacement by the pulp mill sludge.

Energy: incineration and pyrolysis are the common combustion methods used to produce energy from wastes. With pyrolysis (or destructive distillation), the organic matter is heated in the absence of oxygen to produce a mixture of liquid and gaseous fuels and a solid material (mainly carbon). This technology was developed for waste with high carbon contents, such as wood, plastic and oil, but is not yet sufficiently developed for pulp sludge. However, some investigations are being conducted to adapt this technology for this type of waste $[8,71]$. Although some problems and impacts associated with incineration have been reported [70], some authors $[89,90]$ defend its use as an appropriate solution instead of landfilling. In Japan, Matsuto [91] and Tomita et al. [92] demonstrated that a volume reduction of $80-90 \%$ can be achieved through waste incineration. The produced ash would then be landfilled or, preferably, used in building materials. However, some authors highlighted the possible presence of chlorine in the waste, which can lead to problems of corrosion and air contamination due to the formation of organochlorine compounds upon heating. The admissible chlorine content for use as a building material is also very low $(<0.1 \mathrm{wt} \%)$ [61]. The contents of metals and organochlorine compounds were analyzed in the fuel, ash and exhaust gas generated in the incineration of secondary sludge [70]. The metal concentration showed a positive correlation with the formation of polychlorinated dibenzodioxins (PCDDs) and dibenzofurans (PCDFs), demonstrating that incineration requires special control to minimize the potential environmental impacts. Nurmesniemi et al. [12] argued that this type of waste-to-energy process is eco-efficient because the energy content of the waste is used in the form of heat and electricity, thus preventing the extraction and use of virgin energy resources. However, some industrial wastes present high contents of inorganic compounds (that generate ash) or expressive moisture levels, which reduce their calorific potential. The fluidized bed technology has become the best alternative for burning such waste-derived fuels, producing electricity and steam [90, 93].

Some authors also studied the conversion process of fibers present in the primary sludge into ethanol [94-96]. Duff et al. [97] studied the hydrolysis and fermentation of primary sludge resulting from four distinct production processes (acid bisulfite pulping, Kraft, TM and Alpulp) in Canada, and approximately $60 \mathrm{wt} \%$ sludge was transformed into ethanol. In a similar direction, Lark et al. [98] successfully converted $72 \%$ of the cellulose present in the sludge into ethanol in the USA. Chen et al. [99] studied primary sludge 
from four US plants (virgin pulp production and paper recycling). The conversion to ethanol was found to be more efficient when sludge from virgin pulp production is used. Moreau et al. [100] studied the conversion of cellulose present in sludge in ethanol, hydrogen and others compounds by the microorganism Clostridium thermocellum. Results showed that sludge was capable of supporting the growth of C. thermocellum, when used as a carbon source. Microorganism used was able to produce final products with similar concentrations than would be achieved with pure cellulose. After $60 \mathrm{~h}$ of fermentation, $8.5 \mathrm{~mol} / \mathrm{m}^{3}$ of acetate, $11.3 \mathrm{~mol} / \mathrm{m}^{3}$ of ethanol, $8.75 \mathrm{~mol} / \mathrm{m}^{3}$ of lactate, $0.27 \mathrm{~mol} / \mathrm{m}^{3}$ of formate, $11.2 \mathrm{~mol} / \mathrm{m}^{3}$ of hydrogen and $18.41 \mathrm{~mol} / \mathrm{m}^{3}$ of carbon dioxide were produced.

\section{Mixtures of wastes}

Recycling alternatives for waste mixtures from pulp and paper mills and from other industries are also cited in the literature. Again, the agriculture and construction sectors are the most common.

Agriculture: Cabral et al. [30] followed plant growth on soils containing mixtures of ash, primary sludge, dregs and grits; limestone was used as a reference. The correct combination of wastes shows liming potential and might be a substitute for the primary commercial limestone. Potassium and phosphorus concentrations tend to be higher when the waste mix is used, meaning higher fertilizing potential. At the same time, the leached levels of heavy metals are acceptable. Mäkeläa et al. [101] combined blast furnace slag, or steel slag, with ash, sludge and dregs from pulp and paper mill production. The blends were applied in the soil for acid amendments. In particular, mixtures of blast furnace slag with sludge seem to be very promising to replace commercial fertilizers. The high levels of total $\mathrm{Cr}$ and $\mathrm{V}$ found in steel slag are the main limitation. Jordan and Rodriguez [102] also combined ash, dregs and primary sludge with soil, wood bark and other nutrients and tested the growth of several plants, Monterey pines (Pinus radiata), Eucalyptus globulus, rice (Oryza sativa cv. 'Diamante') and duckweed (Lemna minor), in greenhouse and in-vitro conditions. The use of ash and dregs seems to favor the growth of Monterey pines and the germination of eucalyptus seed. The primary sludge and ash promoted the growth of rice.

Construction: silicates and calcium carbonate present in ash behave similarly to the raw materials that are normally used to produce clinker and/or cement. Upon clinkering, the organic fraction of the waste is burned while the mineral fraction is incorporated into the final product [45]. According to Monte et al. [8] and Rajamma et al. [103], the fly ashes from biomass combustion are rich in $\mathrm{SiO}_{2}(28-41 \mathrm{wt} \%)$ and contain smaller amounts of $\mathrm{Fe}_{2} \mathrm{O}_{3}(2.2-2.6 \mathrm{wt} \%)$ and $\mathrm{Al}_{2} \mathrm{O}_{3}$ (6.2-9.3 wt\%). The lime mud consists essentially of calcium carbonate, while the biological sludge can be viewed as an interesting secondary fuel due to its high organic material content. Moreover, biological sludge contains small amounts of oxides also compatible with clinker composition $\left(\mathrm{SiO}_{2}\right.$, $\mathrm{Al}_{2} \mathrm{O}_{3}, \mathrm{CaCO}_{3}$ and $\mathrm{Fe}_{2} \mathrm{O}_{3}$ ). In this sense, Buruberri et al. [61] prepared blends of such wastes and produced belitic and Portland clinkers. The belitic cements showed satisfactory mechanical strength and no signs of deterioration after long periods (strong durability). These cements are (more) environmentally friend than Portland cement because the $\mathrm{CO}_{2}$ emissions are lower. Simão et al. [104] also used pulp and paper mill waste (lime mud, pulp mill sludge and biomass fly ashes) in the production of clinker, achieving results of $\sim 16$ and $\sim 21 \mathrm{MPa}$ in 7 and 28 days of curing, respectively. Castro et al. [26] carried out clinker production field tests, incorporating $0.1 \mathrm{wt} \%$ dregs and $0.25 \mathrm{wt} \%$ grits into the raw mix composition. No negative environmental effects were observed, and such minor incorporation amounts did not alter the current processing conditions. Gemelli et al. [68] studied the influence of ash, fibers, dregs and grits on the properties of mortars formulated with Portland cements CPI-S-32 or CPII-Z-32. Ash and dregs partially replaced the cement, while fibers and grits were substituted for sand. The curing time of the samples ranged from 7 to 28 days, and the results showed that the type of cement and curing time significantly influenced the development of microstructure and the compressive strength. The best results were obtained at 28 days for samples prepared with cement CPI-S-32, ash $(10 \mathrm{wt} \%)$ and grits $(10 \mathrm{wt} \%)$. Martínez-Lage et al. [105] studied the use of green liquor dregs and biomass fly ash to fabricate mortars and concrete. Different mortars were fabricated replacing 10, 20 or $30 \mathrm{wt} \%$ of cement by biomass fly ash and dregs. The compressive and tensile splitting strength increase when $10 \mathrm{wt} \%$ of cement is replaced by biomass fly ash and decrease in all other cases.

\section{CONCLUSIONS}

This work presented a review of case studies about management and proper disposal of waste from pulp and paper mills. The generation and recycling alternatives for ash, lime mud, pulp mill sludge, dregs and grits were evaluated. The assessed studies show that pulp and paper mills are approaching the 'zero waste' goal. Such a situation can be achieved primarily by reducing waste generation and encouraging internal recycling, which is a desirable situation considering the cleaner production concept. However, such wastes can be suitably processed into by-products and then sent to external recycling agencies. Thus, these materials can be used in agriculture, construction, energy and environmental technology. The studies showed that dregs can be used in agriculture as soil amendments, while lime mud can be used in agriculture as well as in environmental technology, mainly in wastewater treatment. Grits can be used in construction. Finally, applications in agriculture, construction and energy use were found to be the main alternatives for pulp mill sludge (primary and secondary). In addition to the physical and chemical characteristics of the wastes, the relationship between supply and demand must also be taken into consideration. For example, soil 
improvement materials are not needed in countries having fertile soils. In this sense, one can conclude that the best destination for the wastes from pulp and paper mills is the one that best adapts to the environmental, economic and social conditions of the region where it is produced. In this context, the construction industry plays an important role because the world's mineral reserves will not be enough to meet future demands. Several limitations interfere with the use of these wastes, highlighting social, political and even bureaucratic issues. New governmental politics should encourage the recycling of these materials to change this scenario. The pulp and paper mill industry has shown a high potential for sustainability.

\section{REFERENCES}

[1] E. Lopes, A. Dias, L. Arroja, I. Capela, F. Pereira, J. Clean. Prod. 11 (2003) 51.

[2] R. Modolo, V.M. Ferreira, L.M. Machado, M. Rodrigues, I. Coelho, Waste Manage. 31 (2011) 370.

[3] European Parliament and of the Council, Directive 2008/98/EC, Official J. Eur. Union 312 (2008) 3.

[4] US Environ. Prot. Ag., Resour. Conserv. Recov. Act $\S 1004(27)$ (2001).

[5] SFIF, "Production and export of pulp and paper" (2014), www.forestindustries.se.

[6] Bracelpa, Estatistica, in: Publicação Mens., S. Paulo (2014).

[7] T. Kinnarinen, M. Golmaei, E. Jernström, A. Häkkinen, J. Clean. Prod. 133 (2016) 953.

[8] M.C. Monte, E. Fuente, A. Blanco, C. Negro, Waste Manage. 29 (2009) 293.

[9] W. Wirojanagud, N. Tantemsapya, P. Tantriratna, Songklanakarin J. Sci. Technol. 26 (2004) 45.

[10] M. Fang, J.W. Wong, Environ. Pollut. 106 (1999) 83.

[11] D.A. Little, R.B. Reneau, D.C. Martens, Bioresour. Technol. 37 (1991) 93.

[12] H. Nurmesniemi, R. Pöykiö, R.L. Keiski, Waste Manage. 27 (2007) 1939.

[13] H.C. Almeida, C.B. Da Silveira, P.R. Ernani, M.L. Campos, D. Almeida, Quim. Nova 30 (2007) 1669.

[14] J.C. Medeiros, J.A. Albuquerque, Á.L. Mafra, F. Batistella, J. Grah, Rev. Bras. Ciênc. Solo 33 (2009) 1657.

[15] J. Zhang, Q. Wang, J. Jiang, Int. J. Hydrogen Energy 38, 6 (2013) 2738.

[16] M.L. Garcia, J. Sousa-Coutinho, Constr. Build. Mater. 41 (2013) 897.

[17] A. Guerrero, S. Goñi, V.R. Allegro, J. Hazard. Mater. 162 (2009) 1099.

[18] M. Ingerslev, M. Hansen, L.B. Pedersen, S. Skov, For. Ecol. Manage. 334 (2014) 10.

[19] M. Odlare, M. Pell, Appl. Energy 86 (2009) 74.

[20] O.-O.E. Ricardo, M.-R.L. Fernando, T.-L. Patricia, Ing. Investig. Tecnol. 15, 3 (2014) 469.

[21] G.R. Qian, J. Shi, Y.L. Cao, Y.F. Xu, P.C. Chui, J. Hazard. Mater. 152 (2008) 196.

[22] T. Ramos, A.M. Matos, J. Sousa-Coutinho, Constr.
Build. Mater. 49 (2013) 343.

[23] R. Siddique, Resour. Conserv. Recycl. 67 (2012) 27.

[24] R. García, R. Vigil de la Villa, I. Vegas, M. Frías, M.I. Sánchez de Rojas, Constr. Build. Mater. 22 (2008) 1484.

[25] F. Cabral, E. Vasconcelos, Environ. Rev. 6 (1998) 55.

[26] F. Castro, C. Vilarinho, D. Trancoso, P. Ferreira, F. Nunes, A. Miragaia, Int. J. Mater. Eng. Innov. 1 (2009) 74.

[27] R. Pöykiö, H. Nurmesniemi, T. Kuokkanen, P. Perämäki, Environ. Chem. Lett. 4 (2006) 37.

[28] L.A. Miranda, R.C.S.S. Alvarenga, P.C.M.J. Pinto, E.D.P. Junior, C.A.B. Carvalho, D.P. Fassoni, L.G. Couto, Rev. Árvore 35 (2011) 1335.

[29] F. Martins, J. Martins, L. Ferracin, C. Dacunha, J. Hazard. Mater. 147 (2007) 610.

[30] F. Cabral, H.M. Ribeiro, L. Hilário, L. Machado, E. Vasconcelos, Bioresour. Technol. 99 (2008) 8294.

[31] R.G. de Souza, "Estudo de pozolana autoclavada baseada em óxido de cálcio derivado da concha da ostra Crossostrea gigas", Diss. Mestr, UFSC (2008).

[32] P. Ribeiro, A. Albuquerque, L. Quinta-Nova, V. Cavaleiro, Resour. Conserv. Recycl. 54 (2010) 1303.

[33] I. Demir, M.S. Baspinar, M. Orhan, Build. Environ. 40 (2005) 1533.

[34] M. Mahmoudkhani, T. Richards, H. Theliander, Process Saf. Environ. Prot. 82 (2004) 230.

[35] F.B. Siqueira, J.N.F. Holanda, J. Environ. Manage. 131 (2013) 1.

[36] C.C. Machado, R.S. Pereira, D.C. De Lima, C.A.B. De, Rev. Árvore 31 (2007) 487.

[37] R. Pérez-López, J. Castillo, D. Quispe, J.M. Nieto, J. Hazard. Mater. 177 (2010) 762.

[38] K. Manskinen, H. Nurmesniemi, R. Pöykiö, Chem. Eng. J. 166 (2011) 954.

[39] T.R. Naik, T.S. Friberg, Y.M. Chun, Cem. Concr. Res. 34 (2004) 1229.

[40] V.C.M. Barretto, "Resíduos de indústria de celulose e papel na fertilidade do solo e no desenvolvimento de eucalipto", Tese Dr., UNESP (2008).

[41] J. Pera, A. Amrouz, Adv. Cem. Based Mater. 7 (1998) 49.

[42] L. Kaluža, M. Šuštaršič, V. Rutar, G.D. Zupančič, Bioresour. Technol. 151 (2014) 137.

[43] T. Mahmood, A. Elliott, Water Res. 40 (2006) 2093.

[44] I. Vegas, M. Frías, J. Urreta, J.T.S. José, Mater. Construcc. 56 (2006) 49.

[45] F. Cernec, Waste Manage. Res. 23 (2005) 106.

[46] S. Krigstin, M. Sain, Pulp. Paper Can. 107, 5 (2006) 29.

[47] V. Niutanen, J. Korhonen, J. Environ. Manage. 65 (2002) 39.

[48] P. Pértile, J.A. Albuquerque, L.C. Gatiboni, A. da Costa, M.I. Warmling, Rev. Bras. Ciênc. Solo 36 (2012) 939.

[49] S.B. Branco, C.B. da Silveira, M.L. Campos, L.C. Gatiboni, D.J. Miquelluti, Rev. Bras. Eng. Agrícola Ambient. 17 (2013) 543.

[50] M. Zambrano, V. Parodi, J. Baeza, G. Vidal, J. Chil. Chem. Soc. 52, 2 (2007) 1169.

[51] A.H. Osteras, I. Sunnerdahl, M. Greger, Water Air Soil 
Pollut. 166 (2005) 17.

[52] L.-A. Lu, M. Kumar, J.-C. Tsai, J.-G. Lin, Bioresour. Technol. 99 (2008) 2210.

[53] Y. Jia, C. Maurice, B. Öhlander, Environ. Earth Sci. 72 (2013) 319.

[54] M. Mäkitalo, "Green liquor dregs as sealing layer material to cover sulphidic mine waste deposits", Lic. Thesis, Luleå Un. Technol. (2012).

[55] M. Mäkitalo, J. Lu, C. Maurice, B. Öhlander, J. Environ. Chem. Eng. 4 (2016) 2121.

[56] X. Ren, J. Clean. Prod. 6 (1998) 349.

[57] J. Zhang, P. Zheng, Q. Wang, J. Clean. Prod. 103 (2015) 828.

[58] J. He, C.R. Lange, M. Dougherty, Proc. Saf. Environ. Prot. 87 (2009) 401.

[59] J. Zhang, Q. Wang, P. Zheng, Y. Wang, Bioresour. Technol. 170 (2014) 270.

[60] J. Zhang, C. Yao, P. Zheng, L. Zang, Int. J. Hydrogen Energy 42 (2017) 12022.

[61] L.H. Buruberri, M.P. Seabra, J.A. Labrincha, J. Hazard. Mater. 286 (2015) 252.

[62] R. Modolo, L. Senff, V.M. Ferreira, J.A. Labrincha, L.A. Tarelho, in: Wastes $1^{\text {st }}$ Int. Conf. (2011).

[63] M. Sutcu, S. Akkurt, Ceram. Int. 35 (2009) 2625.

[64] J. Qin, C. Cui, X. Cui, A. Hussain, C. Yang, S. Yang, Ceram. Int. 41 (2015) 5648.

[65] R. Sun, Y. Li, C. Liu, X. Xie, C. Lu, Chem. Eng. J. 221 (2013) 124.

[66] D.M. Weaver, G.S.P. Ritchie, Environ. Pollut. 46 (1987) 163.

[67] S. Sthiannopkao, S. Sreesai, J. Environ. Manage. 90 (2009) 3283.

[68] E. Gemelli, N. Camargo, J. Brescansin, Mater. Res. 4 (2001) 297.

[69] M.L. Pinheiro, R.C.S.S.A. Alvarenga, B.C. Ribeiro, P.R.S. Júnior, M.S. Sarmet, D.P. Fassoni, Ambiente Constr. 13 (2013) 29.

[70] I. Halonen, J. Tarhanen, J. Oksanen, H. Vilokki, T. Vartiainen, J. Ruuskanen, Chemosphere 27 (1993) 1253.

[71] Y. Lin, X. Ma, Z. Yu, Y. Cao, Bioresour. Technol. 166 (2014) 444.

[72] T. Gea, A. Artola, A. Sánchez, Bioresour. Technol. 96 (2005) 1161.

[73] G.A. Hackett, C.A. Easton, S.J. Duff, Bioresour. Technol. 70 (1999) 217.

[74] J. Jokela, J. Rintala, A. Oikari, O. Reinikainen, K. Mutka, T. Nyronen, Water Sci. Technol. 36 (1997) 181.

[75] Y. Lin, D. Wang, Q. Li, L. Huang, Biomass Bioenergy 35 (2011) 4862.

[76] Y. Lin, J. Liang, C. Zeng, D. Wang, H. Lin, Renew. Energy 108 (2017) 108.

[77] T. Meyer, E.A. Edwards, Water Res. 65 (2014) 321.

[78] J.A. Puhakka, M. Alavakeri, W.K. Shieh, Bioresour. Technol. 39 (1992) 61.

[79] S. Bayr, J. Rintala, Water Res. 46 (2012) 4713.
[80] F. Gallardo, C. Bravo, G. Briceño, M. Diez, Rev. Cienc. Suelo Nutr. Veg. 10, 1 (2010) 48.

[81] F. Gallardo, M. Cea, G.R. Tortella, M.C. Diez, J. Environ. Manage. 95 (2012) S193.

[82] J.C.V. Nkana, F.M.G. Tack, M.G. Verloo, Waste Manage. Res. 17 (1999) 198.

[83] B. Ahmadi, W. Al-Khaja, Resour. Conserv. Recycl. 32 (2001) 105.

[84] R. Yadollahi, Y. Hamzeh, A. Ashori, S. Pourmousa, M. Jafari, K. Rashedi, Polym. Eng. Sci. 53 (2013) 183.

[85] S. Yan, K. Sagoe-Crentsil, J. Environ. Manage. 112 (2012) 27.

[86] C. Martínez, T. Cotes, F.A. Corpas, Fuel Process. Technol. 103 (2012) 117.

[87] J. Soucy, A. Koubaa, S. Migneault, B. Riedl, Ind . Crops Prod. 54 (2014) 248.

[88] A. Donmez Cavdar, H. Yel, S. Boran, E. Pesman, Constr. Build. Mater. 142 (2017) 410.

[89] J. Korhonen, J. Environ. Manage. 63 (2001) 367.

[90] J. Oral, J. Sikula, R. Puchyr, Z. Hajny, P. Stehlik, L. Bebar, J. Clean. Prod. 13 (2005) 509.

[91] T. Matsuto, Waste Manage. Res. 17 (1999) 505.

[92] R. Tomita, H. Hirao, T. Tochigi, T. Tamashige, Key Eng. Mater. 302-303 (2006) 44.

[93] A. Porteous, Waste Manage. 25 (2005) 451.

[94] Z. Fan, C. South, K. Lyford, J. Munsie, P. van Walsum, L.R. Lynd, Bioprocess Biosyst. Eng. 26 (2003) 93.

[95] T. Nikolov, N. Bakalova, S. Petrova, R. Benadova, S. Spasov, D. Kolev, Bioresour. Technol. 71 (2000) 1.

[96] C.V.T. Mendes, C.H.G. Cruz, D.F.N. Reis, M.G.V.S. Carvalho, J.M.S. Rocha, Bioresour. Technol. 220 (2016) 161.

[97] S.J.B. Duff, J.W. Moritz, K.L. Andersen, Can. J. Chem. Eng. 72 (1994) 1013.

[98] N. Lark, Y. Xia, C.G. Qin, C.S. Gong, G.T. Tsao, Biomass Bioenergy 12 (1997) 135.

[99] H. Chen, R. Venditti, R. Gonzalez, R. Phillips, H. Jameel, S. Park, Energy Econ. 44 (2014) 281.

[100] A. Moreau, D. Montplaisir, R. Sparling, S. Barnabé, Biomass Bioenergy 72 (2015) 256.

[101] M. Mäkelä, G. Watkins, R. Pöykiö, H. Nurmesniemi, O. Dahl, J. Hazard. Mater. 207-208 (2012) 21.

[102] M. Jordan, E. Rodriguez, J. Plant Nutr. Soil Sci. 167 (2004) 351.

[103] R. Rajamma, R.J. Ball, L.A.C. Tarelho, G.C. Allen, J.A. Labrincha, V.M. Ferreira, J. Hazard. Mater. 172 (2009) 1049.

[104] L. Simão, J. Jiusti, N.J. Lóh, D. Hotza, F. RauppPereira, J.A. Labrincha, O.R.K. Montedo, Proc. Saf. Environ. Prot. 109 (2017) 106.

[105] I. Martínez-Lage, M. Velay-Lizancos, P. VázquezBurgo, M. Rivas-Fernández, C. Vázquez-Herrero, A. Ramírez-Rodríguez, M. Martín-Cano, J. Environ. Manage. 181 (2016) 863.

(Rec. 20/12/2017, Rev. 14/02/2018, Ac. 19/03/2018) 